\title{
The Effectiveness of High School Affirmations (ADEM) Repatriation: Empirical Evidence from Central Java and Special Region of Yogyakarta, Indonesia
}

\author{
Trisno Martono', Baedhowi ${ }^{2}$, Hery Sawiji ${ }^{3}$, Salman Alfarisy Totalia ${ }^{4}$, Budi \\ Wahyono $^{5}$, Dini Octoria $^{6}$, Sigit Wahyudi ${ }^{7}$, Dowes Ardinugroho ${ }^{8}$, Erna Gesti \\ Fadrusiana ${ }^{9}$ \\ 1,2,4,5,6 Department of Economics Education, Universitas Sebelas Maret, Surakarta, Indonesia \\ ${ }^{3}$ Department of Office Administration Education, Universitas Sebelas Maret, Surakarta, Indonesia \\ alia@staff.uns.ac.id
}

\section{Abstract}

The ADEM repatriation program is one of the government's commitments to address the education problems of children of Indonesian migrant workers (TKI) abroad who have difficulty obtaining access to education services. This study aims to determine the effectiveness of the implementation of the Repatriation ADEM program in the provinces of Central Java and Yogyakarta Special Region. This study uses primary data obtained from questionnaires and interviews. The research sample consisted of four secondary schools (one school in DIY and three schools in Central Java). The results showed that The existence of the ADEM Repatriation program is a government policy that is quite effective in overcoming the education problems of children of Indonesian migrant workers (TKI) who have difficulty obtaining access to education services. However, in some areas the implementation is not optimal, both in management management, learning implementation, and monitoring and evaluation.
Keywords

ADEM; repatriation; effectiveness; Indonesia

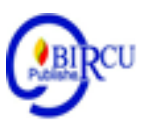

\section{Introduction}

The concept of lifelong education and education for all which was initiated by the United Nation Educational, Scientific and Cultural Organization (UNESCO) is an idea that must be realized, including in Indonesia. The commitment of the Indonesian government to realize education for all is based on the implementation of Law No. 20 of 2003 concerning the national education system, complemented by PP. 47 of 2008 concerning compulsory education and Presidential Instruction No. 5 of 2006 concerning the national movement to accelerate the completion of compulsory 9 year basic education. In addition, education is also one of the basic rights of every citizen that must be fulfilled.

This compulsory education program is expected to provide minimum education for Indonesian citizens to be able to develop their potential so that they can live independently in a community environment or continue their education to a higher level. As a follow-up to the 9-year compulsory education program, the government has also launched a 12-year compulsory education program by providing various facilities for every citizen to receive high school / vocational education.

Problems arise when some school-age children experience various obstacles so that they do not allow them to attend regular school education, for example: social 
(marginalized communities), economic (poor), and geographic (remote and scattered areas), and children of migrant workers abroad. Another problem relates to the opportunity costs that are lost when students go to school, because students find it difficult to enter the legal age to work(Jones et al., 1998). Then, the socialization regarding compulsory education is also not optimal, moreover, government assistance is often not on target. The government has provided various programs to overcome these problems, including: providing educational scholarships for the poor, the open high school program to provide access to education services for junior high school graduates who cannot continue their education due to geography or economy, including the package $\mathrm{C}$ pursuit program to facilitate communities not served access to regular education.

Meanwhile, education services for child migrant workers are quite complex issues for the Indonesian government. Malaysia, which is one of the countries with the largest number of TKI, certainly has to get serious attention by the Indonesian government, especially in terms of difficulties in accessing education for children of TKI. There are many illegal migrant workers who have worked on oil palm plantations in the Sabah region of Malaysia for years. Their children who were born and live near oil palm plantations where their parents work without official documents, of course, cause serious problems related to access to education services. Apart from the problem of completeness of documents, other difficulties related to education services for children of migrant workers in Sabah are the lack of school availability, and the geographical factor where access to schools is very far away.

To overcome this problem, the Indonesian and Malaysian governments agreed to establish Kota Kinabalu Indonesian School (SIKK) so that they could play a role in providing education for Indonesian children in eastern Malaysia. Based on the agreement, the Minister of Foreign Affairs of the Republic of Indonesia through Letter No. 120 / DI / VI / 2008/02/01 dated 16 June 2008 submitted a request to the Indonesian Minister of National Education to establish SIKK and on 1 December 2008 the Kota Kinabalu Indonesian School was officially operational(Indonesian Embassy in Kuala Lumpur, 2018). However, the existence of SIKK has not been able to accommodate Indonesian children of school age, especially those who live in areas far from these schools. The solution was to establish a place for learning activities in several affordable areas, especially around oil palm plantations with the name Community Learning Center (CLC)(Indonesian Embassy in Kuala Lumpur, 2018).

\section{Review of Literatures}

According to Siahaan (2020) the implementation of the 2013 curriculum is characterized by a very fundamental change in the learning process, namely learning that emphasizes active learning. The existence of the CLC is urgently needed to expand access to education services for the children of Indonesian migrant workers who work on oil palm plantations. SIKK as the main school provides services in the form of learning support and funding for SD and SMP CLCs spread across Sabah and Sarawak. The problem is when they have graduated from Junior High School (SMP). Almost every year the SMP exam participants reach 600 students, and of course they hope to continue their education at the SMA level, which is very limited in number(Indonesian Embassy in Kuala Lumpur, 2016). In addition, the Malaysian government regulation states that it no longer provides residence permits for children of migrant workers who have reached the age of 15(Atikbudkl, 2019). 
The Ministry of Education and Culture, through the Directorate of Special Education Development, has made various efforts to overcome these problems, one of which is the implementation of the Repatriation Secondary Education Affirmation (ADEM) program. The ADEM repatriation program is one of the government's commitments to address the educational problems of children of migrant workers abroad who have difficulty obtaining access to education services. This program is focused on providing scholarship assistance to junior high school graduates at SIKK and CLC spread across Sabah Malaysia to obtain quality high school education services in Indonesia which are distributed in 10 provinces, namely: Bali, East Java, Central Java, West Java, DI Yogyakarta, South Kalimantan, North Kalimantan, Lampung and West Nusa Tenggara.

\section{Research Method}

This study uses primary data obtained from questionnaires and interviews. The research instrument is used as a tool to collect data related to policy, implementation, and problems encountered in implementing the repatriation ADEM program. The research sample consisted of four secondary schools (one school in the Special Region of Yogyakarta and three schools in Central Java). The respondents of this study consisted of school principals, classroom teachers, accompanying teachers, regular students, and repatriated ADEM students. The data analysis technique used in this research is qualitative descriptive through four steps, as follows: 1) Processing and preparing the data for analysis, 2) Reading the entire data, 3) Segmenting data into certain categories, and 4) Interpreting data(Creswell, 2012).

\section{Discussion}

In the results and discussion, a description of the character of students and school governance is presented for the Repatriation ADEM Program.

\subsection{Character of Students}

Siregar (2020) states that education does not only educate students to become intelligent human beings, but also educate their character to have good character. Today education in Indonesia in particular is still considered by many to have no problem with the role of education, especially in the scope of the curriculum whose mission is to educate Indonesian children. Seeing the reality in the field that the character of students does not reflect good behavior. Character formation through a hidden curriculum is seen as an important requirement as a complement to the formal curriculum. Character descriptions of Repatriation ADEM students are summarized in Figure 1. Repatriated ADEM students come from SD and SMP from various Community Learning Centers (CLC) spread across the Sabah region of Malaysia. Geographical factors, limited teachers, adequacy and feasibility of facilities and infrastructure make the learning process and evaluation at CLC have a different character from schools in Indonesia. As a result, there are still many repatriated ADEM students who have difficulty adapting to the education system in the new school.

According to Septiadi (2019) students should be introduced from the beginning regarding character education to shape their character. Education for character building basically includes the development of substances, processes and an atmosphere or environment that inspires, provides encouragement, and makes it easier for someone to 1698 develop good habits in everyday life (Siti Irene in Gaol, 2020). 


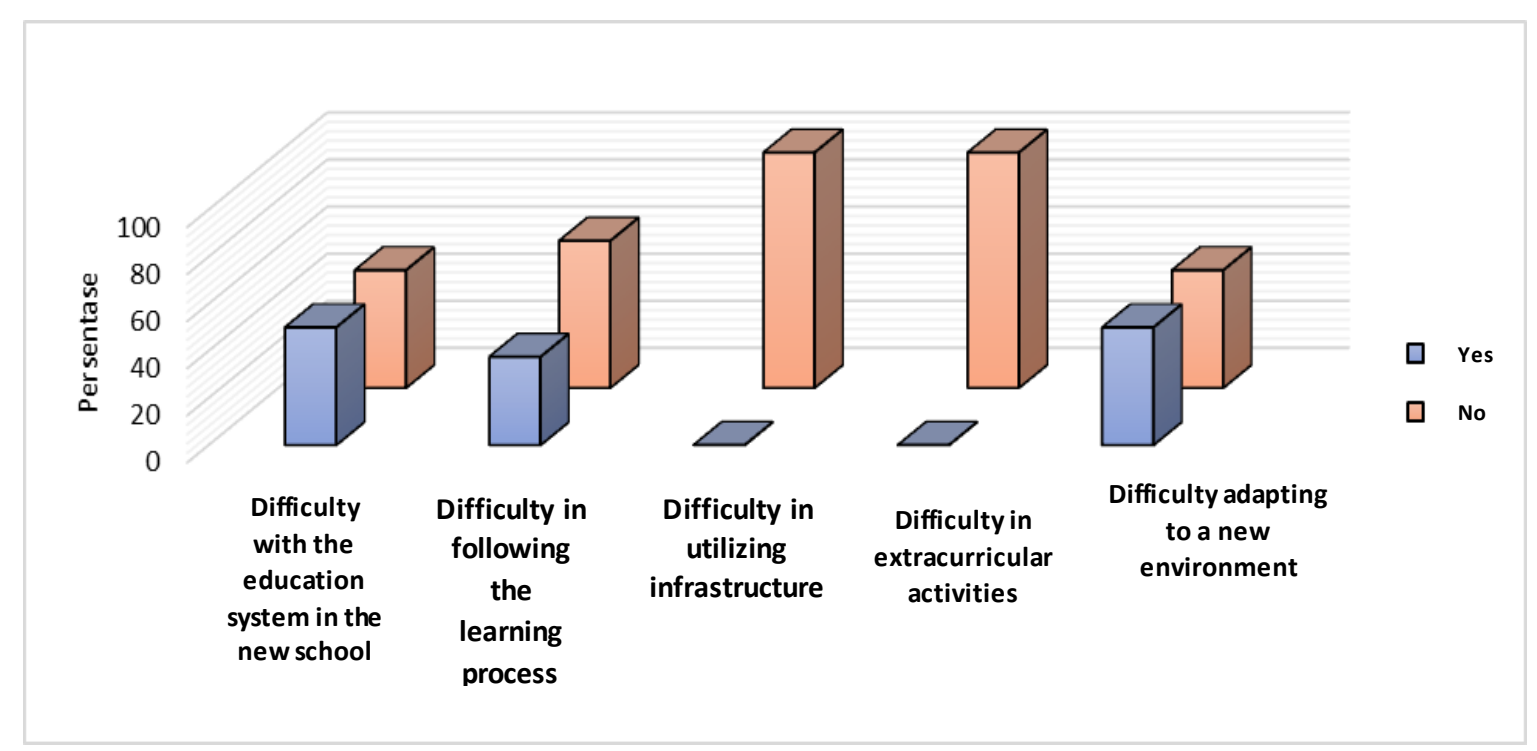

Figure 1. Characteristics of Repatriated ADEM Students

The implementation of the curriculum to meet the National Education Standards (SNP) with a management system, learning and evaluation patterns, and a school culture that is very different from the original school is the main cause of difficulties for Repatriation ADEM students in adapting to the new system. For the learning process, most of the Repatriation ADEM students did not experience difficulties in adapting. However, there are still some students who find it difficult to adapt. The main contributing factor is because ADEM Repatriation students were born and raised in Malaysia who use the Malay language, so they do not master the Indonesian language. Moreover, there are still some teachers who sometimes use local languages when teaching. Another factor is that the average initial ability of Repatriation ADEM students is below the ability of regular students, especially in exact subjects. In addition, the learning model in regular schools is quite different from the original school, especially when learning is carried out in group discussions.

Some of the obstacles faced by schools of origin of Repatriation ADEM students from various CLCs include not having adequate facilities and infrastructure, especially related to the existence of laboratories, libraries, and other learning support infrastructure. However, Repatriation ADEM students do not experience difficulties in utilizing existing facilities and infrastructure in regular schools. Plus, Repatriation ADEM students also do not experience difficulties in extracurricular activities.

Meanwhile, another problem that dominates the existence of Repatriation ADEM students is the norms and culture inherent in them that are different from the norms and culture in schools and the new environment. Repatriation ADEM students are the children of TKI who were born and raised in Sabah Malaysia, so they have very little knowledge about the language, culture, and even the concept of the Indonesian state. When they first entered as ADEM repatriation students, they seemed to lose their identity as Indonesian citizens. This is certainly not surprising because they have never been to Indonesia, and their busy parents who work on oil palm plantations cannot have sufficient space to provide family education and informal understanding of Indonesian norms and culture. 


\subsection{School Governance for the Repatriation ADEM Program}

Students of the Repatriation ADEM program experience various obstacles as described in Figure 1.To overcome these various obstacles, of course, schools need to give special treatment to Repatriation ADEM students, so that they are able to adapt to the academic atmosphere, norms, and culture at school and the surrounding environment. Figure 2 describes the school governance for the Repatriation ADEM program. The school's policy to introduce the school environment in relation to academic activities, infrastructure, and school culture is through the School Environment Introduction Period (MPLS) as given to regular students. Meanwhile, to provide strengthening of the initial abilities of repatriated ADEM students so that they are not much different from regular students,

Based on Figure 2, it can be seen that all sample schools have implemented MPLS and most schools have carried out matriculation activities. However, these activities are included in non-formal activities without a planned program. This is due to the absence of technical guidelines related to MPLS and matriculation activities, so schools provide MPLS and matriculation services non-formally, both in terms of scheduling and substance.

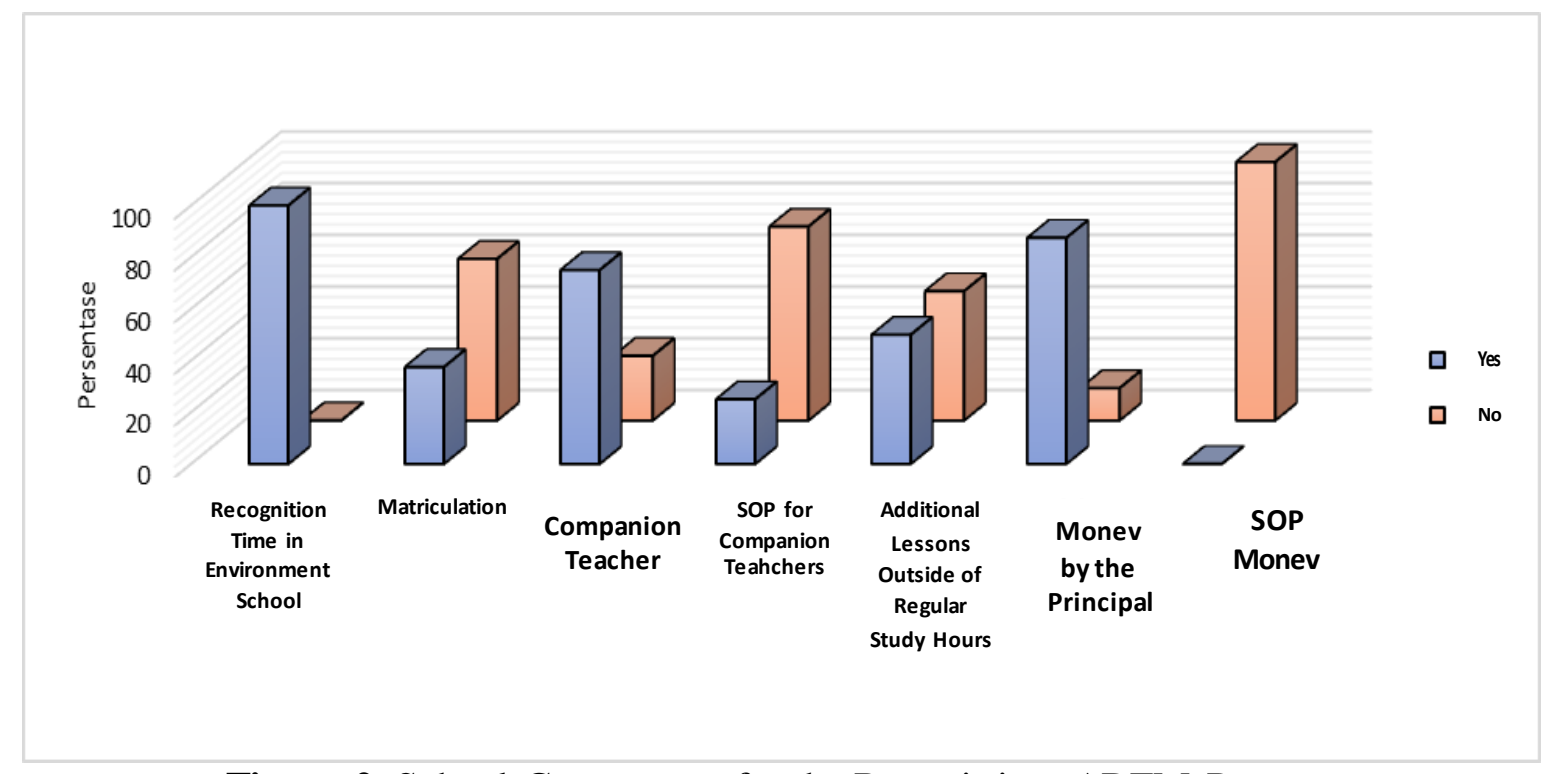

Figure 2. School Governance for the Repatriation ADEM Program

Another policy of schools to help overcome various difficulties due to factors of academic ability and different cultures is to provide companion teachers for Repatriated ADEM students. However, there are still a number of schools that have not provided accompanying teachers for Repatriation ADEM students. Students definitely want something interesting from learning so that they can increase students' interest in learning. High student interest will produce a better understanding and if understanding is good then it will be very easy for students to apply it in daily life. Character education associated with learning fable story texts is very influential on the development of the character of students who are known to be very bad and deviant (Hardianti,2019). Some schools that have provided accompanying teachers are mostly not equipped with mentoring SOPs, so that the implementation of mentoring and coaching activities is not yet clear. In addition, the academic abilities of students that are different from regular students which cause them to experience difficulties in participating in learning activities should consider special 
treatment in the academic field. Some schools have provided additional lessons outside of regular class hours,

Monitoring and evaluation (Monev) is part of the management function which plays a very large role in the quality control system. Internal M\&E related to the effectiveness of the implementation of the Repatriation ADEM program should be carried out by the principal. Based on Figure 2, it is known that most school principals have carried out monitoring and evaluation both in terms of students' academics, learning processes, mentoring, and finance from the repatriation ADEM program. However, the monev mechanism was not well programmed because it was not supported by an SOP. Meanwhile, some schools have not been able to follow up on the results of monev due to budget constraints of the Repatriation ADEM program, including remote coordination with the administrators of the Repatriation ADEM program.

\section{Conclusion}

The existence of the ADEM Repatriation program is a government policy that is quite effective in addressing the education problems of children of Indonesian migrant workers (TKI) abroad who have difficulty obtaining access to education services. The seriousness of the Directorate of Special Education Development and the hard work of implementing schools for the ADEM Repatiation program have had a positive impact on the implementation of this program, both in service and quality of education. Although in some areas the implementation is not yet optimal, both in management management, learning implementation, and monitoring and evaluation.

To overcome these various obstacles, various policies from schools and the government are needed, including the following. First, an introduction to the school environment and matriculation program for Repatriation ADEM students is needed. Second, different academic and cultural characteristics make mentoring programs indispensable. Third, the scholarship granting policy, taking into account several things, including: school administrators (public or private schools), educational units (SMA or SMK), school-owned facilities and infrastructure (having dormitories or not), and the provincial cost of living index. Finally, the optimization of the Repatriation ADEM program is very much determined by the effectiveness of program monitoring and evaluation, by taking into account the following points: it is necessary to have clear and detailed technical guidelines and SOPs,

\section{References}

Atikbudkl. (2019). Berharap Daerah Membuka Jalan Repatriasi Siswa CLC. Retrieved from https://atdikbudkl.org/2019/06/25/berharap-daerah-membuka-jalan-repatriasisiswa-clc

Creswell, J. W. (2012). Research Design: Pendekatan Kualitatif, Kuantitatif dan Mixed: Edisi Ketiga (Translation by Achmad Fawaid). Yogyakarta: Pustaka Pelajar.

Gaol, R.L., and Sitepu, A. (2020). The Influence of Used Good-Based Learning Media on the Value of Chracter Education and Student's Motivation to Study. Budapest International Research and Critics in Linguistics and Education (BirLE) Journal Vol 3 (4): 1696-1703.

Hardianti, V., Adisaputra, A., and Gafari, M.O.F. (2019). Development of Interactive Teaching Materials Using Character Education in Student Fabel Learning in 1st 
Grade in State High School One, Tinggi Raja, North Sumatera, Indonesia. Budapest International Research and Critics in Linguistics and Education (BirLE) Journal Vol 2 (1): 103-115.

Jones, G. W., Nagib, L., Sumono, \& Handayani, T. (1998). The expansion of high school education in poor regions: The case of East Nusa Tenggara, Indonesia. Bulletin of Indonesian Economic Studies, 34(3), 59-84. https://doi.org/10.1080/00074919812331337420.

KBRI Kuala Lumpur. (2016). Layanan pendidikan bagi anak-anak Indonesia di Malaysia.

KBRI Kuala Lumpur. (2018). Refleksi Layanan Pendidikan Anak Indonesia di Malaysia. Februari. Retrieved from http://kbrikualalumpur.org/w/wpcontent/uploads/2018/04/CARAKA-FEBRUARI-for-print.pdf.

Septiadi, H.N., Andayani, and Wardani, N.E.(2019). Planting Base Value of Hardworking Character Education through Ulid Novel. Budapest International Research and Critics in Linguistics and Education (BirLE) Journal Vol 2 (3): 36-44.

Siregar, S.F., Mardianto, and Ahkas, A.W. (2020). Extracurricular Implementation of Islamic Education in Character Building Students in MTs EX PGA UNIVA Medan. Budapest International Research and Critics in Linguistics and Education (BirLE) Journal Vol 3 (2): 965-973. 